\title{
TRADITIONS AND FUTURE OF PUBLIC ADMINISTRATION IN THE FIELD OF E-SERVICES DEVELOPMENT
}

\author{
TRADYCJE I PRZYSZŁOŚĆ ADMINISTRACJI \\ PUBLICZNEJ W ZAKRESIE ROZWOJU E-USEUG
}

\begin{abstract}
The current twenty-first century has become a period of development of the information society, where the Internet is increasingly bravely breaking into every aspect of human life and activity. Thanks to the development of the Internet, many services can be offered to the user, often those which did not have their counterpart several years ago. E-services could have been created through the development of websites as well as the information and communication tools (ICT). These activities are defined as services rendered in an automated manner through the use of modern information technologies. Such facilitation is possible through the implementation of such systems in public telecommunications networks, at the individual request of each, without the simultaneous presence of the parties.

The implementation of e-services which meet the needs of changing challenges is an important area for building relationships connecting a citizen with a specific public administration office. In building such relationships, the key to e-services in Poland is the Trusted Profile, which allows you to use the services provided in a fast and completely secure way.
\end{abstract}

\section{STRESZCZENIE}

Obecny XXI wiek stał się okresem rozwoju społeczeństwa informacyjnego, gdzie Internet coraz odważniej wdziera się w każdy aspekt życia i działalność człowieka. Dzięki rozwojowi Internetu można użytkownikowi zaoferować wiele usług, często 
takich, które nie miały swojego odpowiednika jeszcze kilkanaście lat temu. Poprzez rozwój stron internetowych oraz narzędzi informacyjno-komunikacyjnych (ICT) mogły powstać e-usługi. Działania te są definiowane jako usługi świadczone w sposób zautomatyzowany poprzez użycie nowoczesnych technologii informatycznych. Takie ułatwienie jest możliwe za pomocą wdrażania takich systemów w publicznych sieciach telekomunikacyjnych, na indywidualne żądanie każdego, bez jednoczesnej obecności stron.

Wdrażanie e-usług, które odpowiadają na potrzeby zmieniających się wyzwań, stanowią ważny obszar budowy relacji, które łączą obywatela z konkretnym urzędem administracji publicznej. W budowaniu takich relacji kluczem do e-usług w Polsce staje się Profil Zaufany, który pozwala korzystać z udostępnianych usług w szybki i prosty sposób.

KEYWORDS: public administration, e-services, e-administration, Internet, legal regulations.

SŁOWA KLUCzowe: administracja publiczna, e-ustugi, e-administracja, Internet, uregulowania prawne.

\section{WPROWADZENIE}

Współczesne e-usługi stanowią ważne ogniwo w ekspansji globalizmu oraz są niezbędnym elementem bardzo dynamicznie rozwijającego się społeczeństwa informacyjnego. Za pomocą Internetu można realizować wiele usług, które jeszcze kilka lat temu były niemożliwe do osiągnięcia. Za pomocą Internetu można prowadzić własne firmy, spędzać wolny czas, budować relacje międzyludzkie oraz załatwiać sprawy urzędowe. Również dzięki rozpowszechnianiu stron internetowych, wykorzystaniu narzędzi ICT oraz zaawansowanych technologii informatycznych spora część takich usług oferowana jest automatycznie, bez konieczności fizycznej obecności człowieka. Elektroniczne usługi definiuje się jako działalność administracji publicznej, za pomocą której obywatele załatwiają swoje sprawy urzędowe w sposób szybszy, prostszy i tańszy.

Coraz bardziej dostępne e-usługi stanowią ważne ogniwo w cyfryzacji gospodarki i są kluczowym filarem rozwijającego się społeczeństwa informacyjnego, gdzie odpowiadając na potrzeby zmieniających się wyzwań, stanowią ważny aspekt kształtowania kontaktów i komunikacji łączących obywatela $\mathrm{z}$ urzędem administracji publicznej. Głównym celem opracowania 
jest wskazanie istoty e-usług, wykorzystywanie nowoczesnych technologii w dostarczaniu e-usług, a także wskazanie najważniejszych obszarów wdrażania e-usług. Także wśród sposobów i metod badawczych, jakimi się posłużono w niniejszym tekście, znaczną rolę odegrała metoda opisowa. W celu wnioskowania na podstawie poczynionych obserwacji, a także dokonanych badań, wykorzystano metodę weryfikacji. Natomiast w procesie badawczym wykorzystano analizę retrospektywną (ex post), a także metodę dogmatyczno-prawną, której głównym celem była interpretacja przepisów prawa oraz przeglądu dostępnej literatury przedmiotu.

\section{ISTOTA E-USEUG ORAZ TECHNOLOGIE ICH DOSTARCZANIA}

W literaturze przedmiotu można odnaleźć wiele definicji e-usług. Brak wyodrębnienia jednolitej definicji jest spowodowany faktem, że e-usługi zmieniają się bardzo dynamicznie. Wydaje się zasadne, iż odpowiednim podejściem do oceny e-usług w zakresie funkcjonowania administracji publicznej staje się określenie e-usług wykorzystujące narzędzia i techniki informatyczne. Usługi publiczne są dobrami publicznymi, z których każdego dnia korzysta obywatel. Usługi te stanowią dobra, które charakteryzują się tym, iż są one niewyczerpywalne, bez względu na liczbę osób z nich korzystających. Według B. Kożuch usługi publiczne są realizowane przez administrację publiczną w sposób bezpośredni i przyczyniają się do kształtowania relacji zarówno z obywatelami, jak i z podmiotami gospodarczymi (Kożuch, Kożuch, 2011, s. 35-36). Zatem e-usługi są traktowane jako świadczone usługi wykorzystujące Internet, za pomocą którego dochodzi do zamówienia konkretnej usługi, jej realizacji oraz kontaktu z klientem po jego wykonaniu (Dąbrowska, Janoś-Kresło, Wódkowski, 2009, s. 40-41).

Elektroniczne usługi stają się synonimem współczesnej administracji publicznej. W obliczu wszechobecnych zagrożeń e-usługi świadczone przez administrację publiczną coraz szybciej są wdrażane jako nowe platformy, za pomocą których każdy obywatel załatwia więcej urzędowych spraw. Coraz częściej e-usługi rozumiane są jako nowoczesna metoda dystrybucji usług publicznych, które stają się dość popularne i zastępują tradycyjną formę załatwiania spraw administracyjnych (Filipiak, Dylewski, 2005, s. 453-454). 
W celu lepszego zobrazowania sytuacji należy wskazać, że e-usługa jest rozumiana jako usługa publiczna, która spełnia poniższe warunki:

- jest oferowana w sposób częściowy albo całkowicie zautomatyzowany, wykorzystując do tego procesu odpowiednią technologię informatyczną i informacyjną,

- jest realizowana za pomocą Internetu,

- jest ściśle zindywidualizowana w odniesieniu do każdego odbiorcy,

- jest skoncentrowana na realizacji zadań za pomocą zdalnej usługi,

- jest narzędziem oszczędzającym czas oraz środki finansowe.

W odniesieniu do realizacji spraw urzędowych w ramach tzw. tradycyjnej i klasycznej formy ich załatwiania zastosowanie mają przepisy uregulowane w Kodeksie postępowania administracyjnego. Formalnie i zgodnie z prawem każdy urząd administracji publicznej jest zobligowany do postępowania na podstawie przyjętej procedury załatwiania spraw. Zauważa się jednak, iż w realizacji spraw urzędowych pojawia się konieczność wielokrotnego stawiennictwa osobistego petenta $\mathrm{w}$ danym urzędzie. Jednak uwzględniając odległość między miejscem zamieszkania petenta a urzędem, jego stan zdrowia czy ograniczenia czasowe związane np. z wykonywaniem pracy, może się okazać, że obowiązek osobistego stawiennictwa w urzędzie jest niemożliwy do spełnienia. Zatem wykorzystując nowoczesne technologie informatyczne i komunikacyjne, administracja publiczna może nie tylko zwiększyć swoją skuteczność i efektywność, ale również proponować lepszą wydajność załatwienia sprawy urzędowej bez konieczności osobistego stawiennictwa. Ważne jest przy tym podjęcie przez podmioty administracji publicznej odpowiedniego wyboru w zakresie metody zarządzania konkretnym zadaniem (Kaczorowska, 2013, s. 58-62).

Warto wskazać również na obecność tzw. usług lokalnych, których specyfika polega na tym, że jest to usługa udostępniona przez organ danej jednostki samorządu terytorialnego. Usługę taką można realizować jedynie w urzędzie organu (np. przez wójta, starostę). Jednak usługa o charakterze lokalnym jest udostępniana przez powyższy organ w dwóch przypadkach: 
- gdy przepis prawa wskazuje wprost taki organ (np. radę gminy) właściwy do określenia wzoru dokumentu wykorzystywanego do realizacji danej usługi,

- gdy przepisy prawa nie wskazują w ogóle organu do określenia wzoru; wówczas treść wzoru i stworzenie usługi lokalnej jest również możliwe na podstawie art. 16b ustawy o informatyzacji (art. 16b ustawy o informatyzacji podmiotów realizujących zadania publiczne).

Najbardziej charakterystycznym przykładem usługi lokalnej jest usługa dotycząca składania drogą elektroniczną deklaracji o wysokości opłaty za gospodarowanie odpadami komunalnymi (art. 6m ustawy o utrzymaniu czystości i porządku w gminach).

Usługi publiczne w sposób bardzo widoczny ewoluują w kierunku usług, które coraz bardziej są zrozumiałe i przyjazne klientowi. Dostrzega się przy tym zmieniające się formy prowadzenia działalności pracy urzędu, innej organizacji pracy i zarządzania zadaniami. Taka działalność wymusza na całej administracji publicznej wprowadzenie innowacyjnych mechanizmów świadczenia usług publicznych oraz załatwiania spraw kierowanych zarówno do mieszkańców, jak i podmiotów gospodarczych.

Dlatego odpowiedzią na potrzeby klientów urzędu są działania, które oferują możliwość załatwienia spraw za pomocą e-usług (Aleksiejczuk, 2015, s. 35).

\section{SFERY DZIAŁALNOŚCI ADMINISTRACJI PUBLICZNEJ W RAMACH E-USEUG}

Efektywne i skuteczne funkcjonowanie e-usług w administracji publicznej wymaga zwiększenia roli narzędzi informatycznych i komunikacyjnych w codziennym funkcjonowaniu urzędów. Jest to nic innego jak wdrażanie przez zobowiązane podmioty publiczne zadań publicznych przy zastosowaniu nowoczesnych technologii teleinformatycznych oraz dostępu do Internetu na trzech strategicznych poziomach, tj.:

- wewnętrznej komunikacji w administracji publicznej,

- sprawnej automatyzacji komunikacji z podmiotami realizującymi zadania publiczne za pomocą e-usług,

- oferowanie e-usług wszystkim klientom administracji publicznej. 
Należy mieć także na uwadze, iż w ramach finansowania usług oferowanych za pomocą komunikacji elektronicznej niezbędne staje się zagwarantowanie odbiorcom odpowiedniej jakości systemów zarządzania dokumentami (Jachowicz, Kotulski, 2012, s. 45-49). Zadaniem tych systemów jest zagwarantowanie odpowiedniego pozyskiwania, prawidłowego przetwarzania oraz przechowywania dokumentów, które mają postać dokumentów cyfrowych. Działania te muszą koniecznie uwzględniać strategię każdego urzędu w zakresie zarządzania treścią. Do prawidłowej funkcjonalności takich działań można szczególnie zaliczyć:

- pozyskiwanie i rejestrowanie dokumentów, które wpływają do urzędów w formie papierowej oraz elektronicznej,

- porządkowanie i odpowiednie kwalifikowanie takich dokumentów,

- wyszukiwanie danych,

- zarządzanie obiegiem dokumentów, który jest przyjęty w danym urzędzie,

- kontrolę przyznanych uprawnień w ramach zarzadzania e-usługami,

- archiwizowanie dokumentów (Wrycza, 2010, s. 434-436).

Bez wątpienia należy też wskazać ważną rolę Profilu zaufanego w kształtowaniu i budowie usług elektronicznych. Profil ten jest bezpłatną metodą, której główny cel stanowi potwierdzanie tożsamości obywatela w różnych systemach elektronicznej administracji. Profil zaufany jest traktowany jak odręczny podpis i utożsamia go z konkretnym adresatem. Za pomocą tego narzędzia można wysyłać dokumenty i wnioski do różnych urzędów. Zatem Podpis zaufany potwierdzony profilem zaufanym ePUAP to podpis złożony przez użytkownika konta ePUAP, do którego zostały przyporządkowane informacje identyfikujące zawarte $\mathrm{w}$ takim profilu. Ponadto znajdują się tam dane, które:

- w sposób jednoznaczny określają Profil zaufany ePUAP osoby dokonującej podpis,

- określają czas wykonania podpisu,

- autoryzują przez użytkownika konto ePUAP,

- potwierdzają i chronią podpisem systemowym ePUAP (Lorenz, 2017, s. 27). 
Zagwarantowanie bezpieczeństwa podpisu zaufanego potwierdzonego Profilem zaufanym to zadanie systemu ePUAP. Profil ten jest narzędziem, którego praca opiera się na wykorzystywaniu technologii kryptograficznych stosowanych w centrach certyfikacyjnych, wydających bezpieczny podpis elektroniczny (epuap.gov.pl). Bezpieczny podpis elektroniczny w takim przypadku jest weryfikowany aktualnym kwalifikowanym certyfikatem. Jest on także równoważny pod kątem skutków prawnych z podpisem własnoręcznym, dlatego wymaga szczególnej ochrony, zdecydowanie większej niż podpis zaufany potwierdzony profilem zaufanym (Stefanowicz-Wasilewska, 2014, s. 13).

Przeprowadzając analizę e-usług w administracji publicznej, należy zwrócić szczególną uwagę na główne obszary ich wdrożeń. Coraz bardziej dynamiczny rozwój e-usług w sektorze publicznym można zaobserwować w wielu obszarach, do których można zaliczyć komunikację, administrację, handel, bankowość, ochronę zdrowia, finanse, naukę, turystykę czy kulturę. Dlatego zastosowanie technologii informatycznych i komunikacyjnych w wybranych poniższych obszarach $\mathrm{w}$ administracji publicznej jest rozumiane jako:

- e-komunikacja, czyli wykorzystanie kanałów internetowych do komunikacji pomiędzy nadawcą a odbiorcą, np. komunikatory internetowe, fora czy usługi wideofoniczne (np. Skype),

- e-administracja będąca nieustannym procesem doskonalenia jakości zarządzenia oraz świadczenia usług administracyjnych,

- e-handel, czyli proces sprzedawania i kupowania produktów oraz świadczenie usług, a więc zawieranie różnych transakcji handlowych łączących administrację publiczną z klientami,

- e-bankowość będąca instrumentem koniecznym do dokonywania operacji finansowych niezbędnych do realizacji zadań publicznych,

- e-praca, nazywana również telepracą, jest pracą zdalną, wykonywaną poza siedzibą instytucji publicznej z wykorzystaniem Internetu oraz innych narzędzi biurowych niezbędnych do wykonywania zadań (telefonu, komputera czy specjalistycznego oprogramowania),

- e-nauka (e-learning), czyli odpowiednia technika szkoleń czy realizacja zdalnej nauki na odległość, w której stosuje się różne platformy do prowadzenia tego typu spotkań (ClickMeeting, Microsoft Teams Teams czy platformy edukacyjne: Moodle i Lms Ilias). 
W ramach oferowania przez administrację publiczną e-usług duży stopień jakości świadczenia takich usług jest uzależniony w szczególności od środków finansowych, których źródło pochodzi z budżetu państwa (Singh, Chauhan, 2012, s. 33-38). Bez wątpienia e-usługi świadczone przez administrację publiczną są kluczowym wyznacznikiem odpowiedzialnych struktur publicznych, których zadaniem jest zagwarantowanie obywatelom i podmiotom prywatnym funkcjonowania w nowych realiach cywilizacyjnych. Także coraz większa dostępność i powszechność do usług świadczonych online również w dużym stopniu zależy od podjętej właściwej polityki informacyjnej o wszelkich korzyściach, które są związane z ich wykorzystywaniem. Niestety brak odpowiedniej informacji i powszechnej edukacji na ten temat może przyczynić się do braku wzrostu zainteresowania usługami świadczonymi za pomocą środków komunikacji elektronicznej. Sytuacja taka może wywoływać również nastawienie potencjalnych odbiorców e-usług, że to co nowe może wywołać niepewność oraz obawy, że takie załatwianie spraw urzędowych nie będzie właściwe i odpowiednio zrozumiałe (Ganczar, 2009, s. 38-41).

\section{ZASTOSOWANIE E-USEUG W ADMINISTRACJI PUBLICZNEJ}

Wskazując na istotne czynniki, które determinują rozwój e-usług, należy koniecznie wskazać ważną rolę, jaką odgrywa skuteczna i efektywnie funkcjonująca administracja publiczna. Takie podejście polega w dużej mierze na większym zastosowaniu narzędzi informatycznych i komunikacyjnych w procesie prawidłowego zarządzania publicznego (Batko, Billewicz, 2013, s. 56-57). Należy również budować i nieustannie rozwijać elektroniczną administrację w zakresie kształtowania poniższych relacji:

- w obrębie funkcjonujących urzędów administracji publicznej,

- w obrębie współdziałania urzędów administracji publicznej z podmiotami prywatnymi,

- w obrębie tworzenia odpowiedniej współpracy pomiędzy urzędami administracji publicznej a obywatelami.

Jednak w zależności od sposobu budowania relacji, wykorzystując do tego celu realizację zadań za pomocą e-usług, na liniach administracja publiczna 
- obywatel i administracja publiczna - podmioty prywatne, można wskazać cztery poziomy dojrzałości funkcjonowania administracji publicznej tj.:

- poziom informacyjny, w ramach którego urzędy administracji publicznej zamieszczają informacje w sieci internetowej, gdzie obywatele i przedsiębiorcy mogą uzyskać odpowiednie informacje, przeglądając odpowiednie serwisy internetowe,

- poziom interakcyjny, gdzie obywatele i przedsiębiorcy komunikują się w ramach elektronicznej administracji z pojedynczymi urzędami, jednak urzędy nie zawsze komunikują się z nimi za pomocą środków komunikacji elektronicznej,

- poziom transakcyjny, w którym obywatele i przedsiębiorcy komunikują się w ramach komunikacji zwrotnej z urzędami administracji publicznej,

- poziom integracyjny, za pomocą którego portale internetowe udostępniają informacje tematyczne z różnych urzędów oraz zapewniają możliwość budowania relacji na poziomie transakcyjnym, w ramach którego aktywnie rozwija się społeczeństwo informacyjne (Budziewicz-Guźlecka, 2010, s. 347-354).

Wdrażanie e-usług w szeroko rozumianej administracji publicznej wymaga przy tym zastosowania szerokiej polityki edukacyjnej i informacyjnej. Polega ona na tym, że należy zwiększać świadomość obywatelską na temat możliwości komunikacji z urzędem administracji publicznej, która odbywa się za pomocą zastosowania różnych platform informatycznych. W sytuacji jednak kiedy $\mathrm{z}$ różnych powodów nastąpi przyspieszenie zastosowania tego typu narzędzi, chociażby z uwagi na stany wyjątkowe czy konieczność pozostania obywateli $\mathrm{w}$ domu, taka nauka korzystania $\mathrm{z}$ różnych form komunikacji elektronicznej nastąpi zdecydowanie szybciej, gdyż tego wymagać będzie konkretna okoliczność.

Również niezbędnym warunkiem do zapewnienia właściwego rozwoju e-usług administracji publicznej na poziomie integracyjnym jest wyznaczenie kilku działań, do których należy w szczególności:

- wyodrębnienie procedur załatwiania spraw administracyjnych za pomocą odpowiednich baz i procedur,

- zaprojektowanie repozytorium formularzy wejściowych i wyjściowych, powstałych za pomocą baz formularzy, 
- przygotowanie zbioru aktów prawnych, które stanowią prawny filar realizacji przyjętych w danym urzędzie procedur, możliwy dzięki zastosowaniu odpowiedniej bazy aktów prawnych,

- zaplanowanie kategorii organów administracji publicznej oraz pozostałych podmiotów korzystających z systemu elektronicznej administracji (Grytner, 2008, s. 121).

Uwzględniając powyższe przesłanki, trzeba zauważyć, że projektowanie i wdrażanie systemów teleinformatycznych, które wspierają usługi świadczone przez administrację publiczną, jest działaniem dość skomplikowanym. Wynika to $\mathrm{z}$ faktu, że zachodzi konieczność podjęcia działań organizacyjno-prawnych oraz pilna predestynacja na zdefiniowanie i zastosowanie nowych standardów, które do tej pory nie obowiązywały w administracji publicznej. Jednak zaangażowanie wszystkich odbiorców $\mathrm{w}$ aktywniejsze zastosowanie e-usług rośnie proporcjonalnie $\mathrm{w}$ stosunku do zwiększającej się świadomości na temat konieczności szybszego wdrażania takich usług.

\section{BARIERY I PERSPEKTYWY ROZWOJU E-USEUG W ADMINISTRACJI PUBLICZNEJ}

Znowelizowany niedawno Program zintegrowanej informatyzacji państwa na lata 2014-2022 (Program, PZIP) to strategiczny dokument wskazujący działania Rady Ministrów, których celem jest rozwój polskiej administracji publicznej przy zastosowaniu nowoczesnych technologii cyfrowych (Program zintegrowanej informatyzacji państwa na lata 2014-2022). Program ten za główny cel postawił usprawnienie funkcjonowania całego państwa, a także zapewnienie warunków, które mają ułatwić obywatelowi komunikację z administracją publiczną.

Należy przy tym zauważyć, iż w każdych działaniach trzeba uzupełnić funkcjonalność usług świadczonych on-line i w e-administracji o poniższe możliwości, które już zostały w pewnych obszarach osiągnięte:

- wystawianie i przesyłanie elektronicznych faktur do wszystkich instytucji publicznych za pomocą specjalnie stworzonej platformy, zapewniającej obrót elektronicznymi fakturami, 
- prowadzenie przez podmioty administracji publicznej obsługe reglamentowanej działalności gospodarczej, dotyczącej koncesji, zezwoleń czy różnego rodzaju wpisów do rejestrów,

- zapewnienie sprawnej komunikacji elektronicznej z administracją podatkową (Borowiecki, Czekaj, 2010, s. 82-91),

- zagwarantowanie wszystkim podmiotom gospodarczym pełnego elektronicznego wglądu do spraw podatkowych.

Istnieje zatem realna potrzeba przeprowadzenia cyfryzacji $\mathrm{w}$ administracji publicznej, która daje korzyści wszystkim zainteresowanym. Przedsiębiorcy czy mieszkańcy mogą za pomocą komunikacji elektronicznej załatwiać swoje urzędowe sprawy, a przy tym oszczędzają czas oraz ograniczają koszty. Taka forma współpracy jest jednocześnie wygodnym narzędziem komunikacyjnym. Dla samego urzędu administracji publicznej, a tym samym dla urzędnika, korzyścią zastosowania e-usług jest zapewne możliwość zautomatyzowania dużej części procedur administracyjnych. Trzeba również zauważyć, że obie strony muszą chcieć aktywnie korzystać z systemów informatycznych, a także posiadać techniczne umiejętności do korzystania z elektronicznych platform załatwianych spraw. Ciągle dostrzega się ważny problem, jakim na drodze do cyfryzacji administracji publicznej jest wciąż mały budżet na zadania związane z cyfryzacją działań i usług. Zapewne w nieodległym czasie ta sytuacja musi się zmienić, gdyż polskie urzędy administracji publicznej, korzystając z nowych rozwiązań technologicznych i informatycznych, będą zobowiązane na masową skalę świadczyć usługi publiczne w formie elektronicznej.

Należy także wskazać kilka ważnych przeszkód w rozwoju e-usługi i e-administracji. Bariery te dotyczą w szczególności niezrozumienia prawa, mentalności odbiorców takich usług, gdzie spora część osób nadal opowiada się za osobistym kontaktem z urzędnikiem (Kapler, Piersiala, 2014, s. 205-206). Dostrzega się przy tym również pewne ograniczenia, które są widoczne $\mathrm{w}$ procesie prawidłowej realizacji e-usług, $\mathrm{tj}$.:

- kłopoty integracji systemów informatycznych,

- wciąż niski poziom interoperacyjności systemów teleinformatycznych o charakterze sektorowym i ponadsektorowym, 
- wykluczenie cyfrowe części społeczeństwa,

- brak wystarczającego zaufania społeczeństwa do korzystania z e-usług,

- brak występowania odpowiedniej infrastruktury sprzętowej, brak odpowiedniego oprogramowania czy trudności w dostępie do szerokopasmowego Internetu,

- zbyt niska wiedza o wdrażanych e-usługach,

- obawy urzędników przed utratą pracy związane z wprowadzaniem elektronicznych usług oraz możliwa niechęć pracowników do wprowadzania w tym zakresie zmian,

- niewystarczające umiejętności odbiorców e-usług,

- elektronizacja wersji papierowej dokumentu oraz tradycyjnego procesu obsługi,

- decentralizacja rejestrów i powielenie się danych na różnych szczeblach administracji publicznej,

- brak standaryzacji dokumentacji i procedur w zakresie stosowania i wdrażania e-usług.

Przedstawione bariery często skutkują niedostatecznym wykorzystaniem potencjału technologii informatycznych, które są w posiadaniu samej administracji publicznej.

Pojawiające się przeszkody powodują, że w Polsce e-usługi, zarówno widoczne w biznesie, jak i administracji publicznej, nie są jeszcze wykorzystywane powszechnie. Należy jednak zaznaczyć, że bariery te $z$ każdym rokiem są sukcesywnie pokonywane. O tym fakcie świadczy coraz większa dostępność do Internetu oraz coraz dynamiczniej rozwijające się platformy e-usług. Pojawia się również możliwość korzystania z podpisu elektronicznego, a także zmieniające się podejście samych użytkowników do korzystania z elektronicznych usług oferowanych przez samą administrację. Obserwuje się także zmieniające się podejście do realizacji szkoleń i projektów, których głównym celem jest podejmowanie działań przeciwko wykluczeniu cyfrowemu, często dofinansowanych ze środków finansowych Unii Europejskiej. Przy tym dużą uwagę poświęca się również na rozwój regionalnych platform informatycznych, czego przykładem może być platforma SEKAP (Billewicz, Olszak, Ziemba, 2010, s. 118-134). 


\section{WNIOSKI}

Tworzenie e-usług wymaga zastosowania potencjału technologii informacyjnych i telekomunikacyjnych. Wdrażanie e-usług powoduje również konieczność efektywnego połączenia potencjału informatycznego ze zmianą organizacyjną w funkcjonowaniu jednostek sektora finansów publicznych. To również konieczność dostosowania zadań całej administracji publicznej do nowych wyzwań w zakresie udostępnienia usług za pomocą komunikacji elektronicznej. W tym ciągłym udoskonaleniu świadczenia usług publicznych współczesną administrację cechuje otwartość i przejrzystość w zakresie świadczonych usług, oszczędność czasu, dostępność do takich usług 24 godziny na dobę przez 7 dni w tygodniu, oszczędność pieniędzy na obsługę e-usług czy przyjazność obywatelom i przedsiębiorcom.

Nowelizowany Rządowy Plan Informatyzacji Państwa przyjął, że już od 2015 roku wszystkie akty prawne i wzory dokumentów w administracji publicznej są ogólnodostępne za pomocą platformy ePUAP. Urzędy administracji publicznej z większym zaangażowaniem korzystają z możliwości, jakie daje Internet. Dostrzega się również zmiany w zakresie realizacji zadań publicznych. Urzędy coraz częściej posługują się elektronicznymi fakturami, a dorośli internauci za pomocą komunikacji elektronicznej załatwiają np. swoje sprawy podatkowe czy komunikacyjne. Zatem najważniejszym celem administracji publicznej w najbliższym okresie powinno być również podniesienie poziomu zaufania do e-usług wśród klientów administracji publicznej.

Przeprowadzone założenia wskazują, że w obszarach zmian technologicznych w administracji publicznej, wykorzystującej aktywnie narzędzia komunikacyjne i elektroniczne, nastąpił widoczny progres. Bardzo pozytywnym efektem wyników jest zwiększająca się dość dynamicznie wśród obywateli dostępność do e-usług, które gwarantują w sposób skuteczny i oszczędny realizację spraw urzędowych. Zatem kluczowe wnioski płynące $z$ analizy i przeprowadzonych badań skierowane są na zintensyfikowaną politykę informacyjną i edukacyjną w zakresie wykorzystania e-usług. Zwiększająca się przy tym świadomość społeczna na temat korzyści, jakie daje dynamiczny rozwój e-usług w Polsce, bez wątpienia przyczyni się do większego zainteresowania, a tym samym zwiększonego wykorzystania możliwości, jakie w coraz większym stopniu oferuje administracja publiczna za pomocą dostarczanych e-usług. 
Dynamicznie rosnąca konkurencja oraz wszechobecna rewolucja cyfrowa powoduje, że e-usługi administracji publicznej zaczynają odgrywać coraz ważniejszą rolę, zarówno dla państwa, jak i społeczeństwa. Rozwijająca się informatyzacja administracji publicznej jest konieczna. Argumentem przemawiającym na tę okoliczność jest chociażby członkostwo Polski w Unii Europejskiej i nałożone na poszczególnych członków zobowiązania w zakresie wdrażania elektronicznych technologii. Ważne zatem staje się również podejmowanie przez administrację publiczną aktywnej polityki informacyjnej i edukacyjnej w zakresie wykorzystania możliwości, jakie dostarczają e-usługi. Istotne jest także, aby sprawy urzędowe były załatwiane w sposób prostszy i przejrzysty, korzystając z możliwości, jakie oferuje Internet, co w nieodległym czasie stanie się standardem w codziennym życiu.

\section{Bibliografia}

Aleksiejczuk A. (2015). Determinanty rozwoju e-ustug $w$ administracji publicznej $w$ Polsce, Ekonomia i zarządzanie, 1, s. 32-43. ISSN 2080-9646.

Batko K., Billewicz G. (2013). E-ustugi w biznesie i administracji publicznej, Studia Ekonomiczne, 136, Uniwersytet Ekonomiczny w Katowicach. ISSN 0239-6416.

Billewicz G., Olszak C.M., Ziemba E. (2010). Administracja publiczna wobec wyzwań społeczeństwa informacyjnego i gospodarki opartej na wiedzy, [w:] Kierunki rozwoju społeczeństwa informacyjnego i gospodarki opartej na wiedzy w świetle śląskich uwarunkowań regionalnych, C.M. Olszak, E. Ziemba (red.), Katowice: Uniwersytet Ekonomiczny. ISBN 9788372466273.

Borowiecki R., Czekaj J. (2010). Zarzadzanie zasobami informacyjnymi w warunkach nowej gospodarki, Warszawa: Difin. ISBN 9788376411705.

Budziewicz-Guźlecka A. (2010). Rola e-administracji $w$ rozwoju społeczeństwa informacyjnego, Zeszyty Naukowe Uniwersytetu Szczecińskiego Nr 598, Ekonomiczne Problemy Usług, 58, E-gospodarka w Polsce. Stan obecny i perspektywy rozwoju. Część II. ISSN 1896-382X.

Dąbrowska A., Janoś-Kresło M., Wódkowski A. (2009). E-usługi a społeczeństwo informacyjne, Warszawa: Wydawnictwo Difin. ISBN 9788372519825.

Filipiak B., Dylewski M. (2005). Usługi publiczne. W: Wspótczesna ekonomika usług, S. Flejterski, A. Panasiuk, J. Perenc, G. Rosa (red.), Warszawa: Wydawnictwo Naukowe PWN. ISBN 9788301155223. 
Ganczar M. (2009). Informatyzacja administracji publicznej; nowa jakość usług publicznych dla obywateli i przedsiębiorców, Warszawa: CeDeWu Sp. z.o.o. ISBN 9788375561043.

Grytner R.A. (2008). Zintegrowane biblioteki procedur. Narzędzie do budowy taniej, sprawnej i nowoczesnej administracji publicznej, eAdministracja, 6. ISSN 18956335.

Singh A.J., Chauhan R. (2012). Technology Challenges in E-Service Accessibility, Journal of Engineering and Technology, 2(1). ISSN 2180-3811.

Jachowicz M., Kotulski M. (2012). Forma dokumentu elektronicznego w działalności administracji publicznej, Warszawa: Difin. ISBN 9788376416632.

Kaczorowska A. (2013). E-ustugi administracji publicznej w warunkach zarzadzania projektami, Łódź: Wydawnictwo Uniwersytetu Łódzkiego. ISBN 9788375259322.

Kapler M., Piersiala L. (2014). E-usługi w administracji publicznej, Roczniki Kolegium Analiz Ekonomicznych, 33, Technologie informatyczne w administracji publicznej, Szkoła Główna Handlowa. ISSN 1232-4671.

Kożuch B., Kożuch A. (2011). Usługi publiczne. Organizacja i Zarządzanie, Kraków: Monografie i Studia Instytutu Spraw Publicznych Uniwersytetu Jagiellońskiego. ISBN 9788393458400.

Lorenz K. (2017). Podpis zaufany $w$ rozwoju e-administracji, Studia Informatica Pomerania, 3(45). ISSN 2451-0424.

Program zintegrowanej informatyzacji państwa na lata 2014-2022 stanowiący załącznik do Uchwały Nr 109/2019 Rady Ministrów z 24 września 2019 r.

Sitek B. (2016). Zasady etyczne stosowane $w$ cyberprzestrzeni. W: B. Sitek, J. Knap, S. Sagan, Ł. Roman, Nowoczesne narzędzia informatyczne w przeciwdziałaniu zagrożeniom bezpieczeństwa, Józefów: wyd. WSGE, s. 71-84. ISBN 9788362753789.

Sitek M. (2018). Prawne ramy bezpieczeństwa jednostki w cyberprzestrzeni. Journal of Modern Science, 37(2), s. 177-189. Pobrane z https://doi.org/10.13166/jms/91855 (dostęp 2.07.2020 r.).

Stefanowicz-Wasilewska M. (2014). Bezpieczny profil elektroniczny czy profil zaufany - co bardziej przydatne dla przedsiębiorcy, Gazeta Podatkowa, 61 (1102), 31 lipca 2014. Pobrane z: https://www.gofin.pl/firma/17,2,145,132347,bezpieczny-podpis-elektroniczny-czy-profil-zaufany-co.html (dostęp 2.07.2020).

Such-Pyrgiel M. (2019). Człowiek $w$ dobie cyfrowej transformacji. Studium socjologiczne, Toruń: wyd. Adam Marszałek, s. 163-169. ISBN 9788366220966. 
Sylwestrzak M., Bartoszewska B., Czarnecki R. (2016). Rozwój e-usług publicznych $w$ Polsce na przykładzie projektów realizowanych przez administrację publiczna $w$ ramach 7. osi POIG, Telekomunikacja i Techniki Informacje, 1-2. ISSN 1640-1549.

Ustawa z 13 września 1996 r. o utrzymaniu czystości i porządku w gminach (tekst jedn.: Dz.U. z 2019 r. poz. 2010 ze zm.).

Ustawa z 14 czerwca 1960 r. Kodeks postępowania administracyjnego (tekst jedn.: Dz.U. z 2020 r. poz. 256 ze zm.).

Ustawa z 17 lutego 2005 r. o informatyzacji działalności podmiotów realizujących zadania publiczne (tekst jedn.: Dz.U. z 2020 r. poz. 346 ze zm.).

Wrycza S. (2010), Informatyka ekonomiczna, Warszawa: PWE. ISBN 9788320818635. 